\title{
MARSÍLIO DE PÁDUA SOBRE A TRANSLAÇÃO DO IMPÉRIO
}

Traduçäo de José Antônio de C. R. de Souza*

\section{Sobre a Translação do Império}

Os capitulos deste tratađo são doze.

O primeiro capítulo versa a respeito do objetivo do que há de ser tratado.

O segundo mostra de que modo o Império Romano permaneceu sem alteração durante trezentos e cinqüenta e quatro anos e cinco meses, governado por trinta e três imperadores.

O terceiro aborda porque os Orientais, a saber, os Persas, os Árabes, os Caldeus e outras nações limitrofes se subtraíram do domínio do Império Romano.

O quarto capitulo discorre sobre quais foram os principais povos que se rebelaram por causa das mencionadas circunstâncias.

O quinto trata do princípio e da đisposição reiativa à transferência do Império dos Gregos para os Francos.

O sexto aborda de que modo Pepino, no tempo de Zacarias, papa romano, foi elevado de mordomo a rei dos Francos.

O sétimo capítulo discorre de que maneira Pepino, rei dos Francos, por solicitação da Igreja Romana, veio à Itália lutar contra Astolfo, rei dos Lombardos, o venceu e restituiu à Igreja Romana seus bens temporais.

O oitavo trata do modo como, no tempo do papa Adriano, Carlos Magno foi estabelecido patrício da cidade, e como lhe foi concedido o controle sobre a Sé Apostólica.

O nono mostra de que maneira foi efetuada a translação do Império Romano dos Gregos para os Francos.

O décimo considera como o Império foi transferido dos Francos ou Gauleses para os Germânicos.

O décimo primeiro discorre acerca do modo como foram estabelecidos os eleitores do Império Germânico.

O décimo segundo capítulo recapitula o que foi anteriormente abordado.

* Universidade Federal de Goiás.

\begin{tabular}{|l|l|l|l|l|l|}
\hline VERITAS & Porto Alegre & v. 43 & $n^{\circ} 3$ & Setembro 1998 & p. 703-723 \\
\hline
\end{tabular}




\section{Capítulo primeiro}

No Defensor da Paz discorremos a respeito da instituiçäo do principado dos Romanos e de qualquer outro principado, de uma nova transferência ou outra mudança referente ao mesmo, bem como tratamos da maneira e por intermédio de quem, isto pode vir a ser feito, conforme a razäo e o direito.

Agora, nestas páginas, recorrendo às crônicas e histórias, queremos criticar acuradamente a obra intitulada Translação da sé imperial, escrita pelo venerável Landolfo Colona, sátrapa romano, porque divergimos da sua opinião, expressa em certas passagens da mesma, e especialmente pelo fato de aí ter lesado os direitos do império, fundamentado apenas em seu ponto de vista, sem, no entanto, ter apresentado uma comprovação suficiente.

Portanto, em primeiro lugar, trataremos a respeito da translação da sé romana imperial, dizendo de que modo e por intermédio de quem ou de quais pessoas ela efetivamente ocorreu, tendo passado dos romanos para os gregos, e depois, destes aos gauleses ou francos, e enfim, dos francos para os germânicos.

Contudo, antes, convém ressaltar que o termo império romano tomado em um sentido, às vezes, significa apenas a monarquia ou principado real da vila ou cidade de Roma. Qual foi ela, desde a sua origem, ficará de certo modo patente através do que a seguir irá ser exposto.

Noutra acepção, Império Romano quer dizer a monarquia universal ou geral exercida sobre todo mundo, ou ao menos, sobre a maior parte das provincias, como o foi o principado da cidade de Roma, no decorrer de sua evolução. Tendo, pois, em mente esta acepção, é nosso propósito tratar acerca da translação do império.

Por isso, começando do princípio, conforme a ordem [cronológica dos fatos], em primeiro lugar, narraremos acerca da origem da vila ou cidade de Roma e sobre o começo de sua exígua monarquia, depois, a respeito de sua dilatação ou expansão, até ter se transformado em uma monarquia ou em um principado supremo exercido sobre todo mundo. Em seguida, descreveremos como, no transcorrer do tempo, ocorreu sua transferência de sede em sede ou de nação para nação.

Portanto, baseados em relatos históricos fidedignos, começaremos tratando do surgimento da vila de Roma e de sua primitiva organização. Com efeito, em seguida à destruição da grandiosa Tróia, Enéias dela fugindo, chegou por mar à Itália, e aí fundou o império romano, no local onde, hoje, encontra-se Roma, e neste lugar, porque o mesmo the agradou, ele semeou a origem da raça romana. Com o passar do tempo, esta semente crescendo, transformou-se em uma planta muito singular, a qual espalhou seus ramos por todo o mundo, sob todos os climas, como se fora um grão da mostarda, que, embora seja tão pequeno, transforma-se uma planta que ultrapassa admiravelmente as demais, e sob cuja sombra, as plantas, isto é, todos os reis do mundo, príncipes e tiranos, juntamente com os povos, em geral, viviam na quietude da paz.

Na verdade, os romanos que descendiam de Enéias, por intermédio do exercicio das armas, da disciplina castrense, da utilização do exército, da liberdade pacífica, do culto da justiça, do respeito às leis, dos pactos de amizade celebracios 
com os povos vizinhos, da maturidade dos seus conselhos, da seriedade das suas palavras e obras, conseguiram submeter todo orbe ao seu poder. Com efeito, o povo romano, desde o rei Rômulo até César Augusto, durante setecentos anos, levou seu exército corajosa e poderosamente por todo o mundo, e graças à sua própria força, submeteu todos os reinos do orbe, para que, os que viessem a ler seus feitos magníficos se deparassem com as façanhas, não de um único povo, mas de todo o gênero humano, e também, a fim de que acreditassem que, para construir o seu Império, lutaram contando com a virtude humana e a fortuna.

\section{Capítulo segundo}

De acordo com algumas pessoas, o Império Romano principiou com Júlio César, mas o que é mais verdadeiro é que ele começou com Otaviano Augusto, primeiro imperador dos Romanos. De fato, consoante a verdade histórica, embora, Júlio César tivesse sido o primeiro que arrebatou para si a monarquia dos Romanos, ele não foi imperador, mas antes um violador e um usurpador da República, e por isso, seu nome não consta do catálogo dos príncipes dos Romanos.

Ora, o Império até Constantino ${ }^{1}$ magno foi governado por trinta e três imperadores e permaneceu em Roma durante trezentos e cinqüenta e quatro anos e cinco meses. Mas no sétimo ano de seu governo, Constantino mudou a sede do Império, transferindo-a para o Oriente, junto à cidade de Bizâncio, atualmente chamada Constantinopla, ${ }^{2}$ ai estabelecendo a sé imperial, a qual, de acordo com os direitos imperiais, também gozou das prerrogativas da antiga Roma. Ele também confiou o governo de Roma e de outras provincias da Itália, ao bem-aventurado Silvestre, ${ }^{3}$ então, pontífice romano, e aos seus sucessores, como o relatam algumas histórias, nas quais igualmente se diz que à instância dos clérigos da Cidade, aquele pontífice lhes conferiu certas dignidades senatoriais.

Na verdade, tais pessoas, que àquela época, eram chamados clérigos da Igreja Romana, hoje são designados por cardeais, mas antes do papa Silvestre, eles eram simplesmente chamados clérigos ou sacerdotes da Igreja Romana. Não tinham títulos concernentes às honras e à dignidade [dos cargos que desempenhavam], mas eram responsáveis quanto aos ofícios de pregar, de sepultar os mártires, de batizar e de ouvir confissões. Com efeito, estas incumbências foram estabelecidas muito tempo antes de Silvestre, a saber, desde a época de Cleto e Anacleto, de Dionísio e de Marcelino. Mas durante o pontificado de Silvestre eles receberam o título da dignidade e aquela prerrogativa e a honra que o Senado possuía à época de Constantino. Da leitura de nosso Defensor da Paz é possivel verificar se tal procedimento foi legitimo ou não.

No entanto, a par destes dados, é preciso ressaltar que Martinho Polonês, indica em sua crônica o número dos cardeais, dizendo que são cinqüenta e dois, repartidos em três grupos, a saber, 6 bispos, 28 presbíteros e 18 diáconos, dos

1 306/313/324-337. A primeira data corresponde à sua aclamação pelas legiōes da Bretanha, com a morte de seu pai, Constâncio Cloro. A segunda, ao restabelecimento da diarquia, juntamente com Licínio. A última, à restauração da monarquia imperial, após ter vencido e morto o antigo colega.

2 Ela foi erigida como tal em 11 maio de 330.

3 Seu pontificado durou de 314 a 335 . 
quais, alguns deles, sentam-se ao lado do Sumo Pontífice, e tal é o caso dos bispos, os quais durante as solenidades usam cadeiras ao lado do senhor papa. Outros são assistentes, como os presbíteros, os quais assistem ao senhor papa, todas as semanas, durante a celebração das missas e a recitação das horas canônicas. Os demais, isto é, os diáconos estão vinculados às suas incumbências, os quais desempenham os seus próprios ofícios. São eles, pois, que vestem o papa e o servem ao redor do altar. Mas conforme a atribuição de seus títulos, feita primeiramente por Cleto, depois por Anacleto e mais tarde por Marcelino, há outros mais, no entanto, abordar este assunto, agora, não é relevante ao nosso propósito.

Ora, os escritores das histórias, em geral, dizem que o bem-aventurado Silvestre foi o primeiro a nomear cardeais tais clérigos. De fato, anteriormente, como já foi dito, eles eram chamados presbiteros da Cidade de Roma, como o mostra claramente a História Eclesiástica de Eusébio [de Cesaréia], bem como o que se lê acerca de Novaciano, presbitero da Igreja Romana, o qual, aspirando ascender ao sumo pontificado, empenhou-se em impedir a promoção do papa Cornélio. ${ }^{4}$

\section{Capítulo terceiro}

Constantino, bem como os imperadores romanos que o sucederam pacificamente, exerceram um domínio sobre o Oriente até o vigésimo segundo ano do governo do imperador Heráclio, ${ }^{5}$ ocasião esta, em que todos os povos orientais se subtrairam do dominio dos latinos. Mas, em geral, ignora-se por qual motivo e de que modo eles procederam assim, por isso, julgo conveniente apresentar a razão e discorrer de que maneira os referidos Orientais se separaram completamente dos gregos e dos latinos, tanto subtraindo-se do seu domínio político, quanto de seu culto. Na verdade, o motivo que levou os Orientais, isto é, os Persas, os Árabes, os Caldeus e outros povos vizinhos a se subtraírem do domínio do Império Romano foi o principado tirânico de Heráclio.

Com efeito, após a grande vitória que Heráclio obteve sobre os Persas, ${ }^{6}$ ele não só os passou a oprimir mediante uma dominação muito cruel, mas também outras nações vizinhas, as quais, por tal motivo, em comum acordo, decidiram procurar uma ocasião para se rebelar. Mas para se subtraírem efetivamente daquela mencionada sujeição, de modo que nunca mais fossem reconduzidos à mesma, por sugestão de Maomé, ${ }^{7}$ que, então, vivia entre os ricos e poderosos persas, eles adotaram uma religião diferente, de maneira que por causa da diversidade de crença e de fé ou de seita, não retornaram à dominação anterior, seguindo o exemplo de Jeroboão, ${ }^{8}$ o qual deu um culto diferente às dez tribos que o seguiram, a fim de que elas não mais retornassem à dominação anterior e legitima.

4 Governou a Igreja de 251 a 253.

5 Imperou em Constantinopla de 610-641.

6 Tudo indica que a passagem esteja a se referir à vitoriosa campanha do imperador na Mesopotêmia, culminada com a morte de Cosroés II e a solicitação de trégua, da parte de seu sucessor, Kawadh, em 628, conquanto a guerra contra os persas tivesse começado em 622.

7 Viveu entre 570-632.

8 General israelita e $1^{2}$ rei da Samaria, a partir de 926, em seguida à morte de Salomão (966-926). 
Foi também o que os gregos semelhantemente fizeram, pois, querendo se separar da obediência à Igreja Romana, adotaram um culto ou ritual diferente nas celebrações eclesiásticas, e assim, caíram conscientemente em diversos erros. De fato, todos os seus monges, os quais conservam e alimentam os cismas, ou são nestorianos ou eutiquianistas, ou arianos ou jacobitas ou hebionistas. ${ }^{9}$ Portanto, foi isso que aconteceu com aqueles povos e nações daquelas regiões, em que ocorreram as referidas rebelião e desobediência. Na verdade, a fim de que tal rebelião perdurasse, transformaram os cismas numa seita, com o propósito de, não apenas de se subtrairem do Império, mas também de romperem com Cristianismo, inclusive, adotando para si certos rituais comuns da lei de Moisés e da evangélica, como é evidente no Alcorão.

Daí, é preciso ressaltar, que certas seitas heréticas foram muito familiares a Maomé e à lei dos sarracenos, como está preservado no mencionado Alcorão, e tal é o caso dos Nestorianos, a quem Maomé ordena honrar. Por isso, Ricardo [de Cluny] narra em suas crônicas, que um certo monge nestoriano, chamado Sérgio, durante um longo tempo instruiu Maomé, razão pela cual os nestorianos possuem grandes mosteiros nos domínios dos sarracenos.

\section{Capitulo quarto}

Por conseguinte, tendo narrado o motivo e o modo através do qual os citados orientais se subtraíram da dominação dos gregos e dos latinos, vejamos quais foram os principais povos que provocaram tal sedição, conforme as mencionadas circunstâncias, pois, eles não só tiveram a audácia de se rebelar e de desobedecer, mas tendo procedido assim, ainda, invadiram hostilmente territórios pertencentes ao império romano e ao imperador, e outras regiões vizinhas.

O [mencionado] Ricardo em sua crônica, Martinho Polonês, Isidoro [de Sevilha] e Aimo [de Fleury] no livro IV do De Gestis Francorum concordam entre si, ao dizer que a principal nação que se ergueu com a mencionada audácia partiu da Arábia e dos sopés do Cáucaso, a qual, segundo Jerônimo, em suas crônicas, chama-se nabatéia, cujo nome provém de Nabot, primogênito de Ismael, daí que teriam de ser designados por agarenos ou ismaelitas, e não por sarracenos.

Esta nação, devastando regiões do Império, chegou à Siria e à Jưdéia. ${ }^{10}$ Contra ela foi enviado um numeroso exército do imperador Heráclio, o qual, no entanto, foi completamente derrotado pelo inimigo. Cento e cinqüenta mil homens do mencionado exército do imperador foram mortos. Lê-se, contudo, que os inimigos deram prova de humanidade, enviando todo espólio ao imperador, por intermédio de legados.

9 O trecho refere-se às principais heresias que grassaram, por motivos civersos, nas províncias orientais, em especial, na Palestina, Siria e Egito. Nestorianos, por exemplo, foram os seguidores do Patriarca Nestório de Constantinopla (428-432) propositor da heresia, segundo a qual, Maria era apenas mãe do Cristo-homem. Os eutiquianistas ou monofisitas foram os seguidores de Eutiquio arquimandrita constantinopolitano e antinestoriano, que propôs a heresia, segundo a qual, só há uma natureza em Cristo, a divina.

10

Com efeito, os árabes conquistaram as provincias da Síria em 636, e da Palestina, ao final de 637 e do Egito em 641-642, pouco depois da morte de Heráclio. O reino persa foi conquistado entre 636642. 
Todavia, Heráclio recusou esse espólio ou presente. Foi, então, que ele recorreu ao auxílio dos Alanos, os quais, dizem, provieram dos montes Cáspios, onde, consoante os relatos das sobreditas histórias, eles tinham sido alojados por Alexandre [Magno]. Ele reorganizou o exército e reuniu um incomensurável número de combatentes.

Dois generais comandavam os sarracenos, os quais instruiram na arte da guerra duzentos mil soldados. Ambos os exércitos não distantes um do outro, estavam prontos e preparados para a bataiha, mas na noite que precedeu o dia do combate, no acampamento dos gregos, cinco mil e dois soldados foram encontrados mortos em suas camas. O restante do total do exército, tomado pelo medo e pelo terror, fugiu em várias direções, deixando todo o império para os inimigos.

Ora, Heráclio, tendo recebido a notícia de tamanha calamidade, não estando seguro de que podia resistir, por causa da tristeza caiu doente, e quase desesperado, deixou-se abater por uma doença da alma, e então, segundo determinadas histórias, foi corrompido pela heresia de Eutiquio, ${ }^{11}$ e se uniu em matrimônio com uma filha de sua irmã, chamada Martinha. Outras histónias, porém, reiatam que, antes do predito conflito, ele já havia sido corrompido pela mencionada heresia.

Após esses acontecimentos, como Ricardo relatou em suas crônicas, o exército dos árabes e nabateus foi aumentado com os habitantes de diversas províncias vizinhas, a saber, com os caldeus, amonitas e moabitas, a quem Maomé havia se juntado, cujo principado se localizava na Arábia.

Este Maomé, instruído na magia, como se diz, mas, acredito que, antes, conduzido por sua prudência, com o pretexto de desprezar o Império, os convenceu quanto a adotar um modo de vida igual ao seu, e a fim de dilatar enormemente a dominação sobre o povo, o enganou com sua arte e o desviou da fé, afirmando que eles não podiam possuir um principado, a não ser se renunciassem à fé cristã e observassem os seus preceitos. Maomé passou, em geral, a ser tido na conta de profeta por aqueles povos, tendo simulado também possuir em si mesmo algum dom divino, e assim, enganando os homens com algumas artimanhas que thes mostrou.

Foi igualmente através dessas práticas ludibriosas, que Maomé seduziu, a tal ponto, uma certa viúva nobre e poderosa, chamada Cadija, natural da província de Corassam, vindo a contrair matrimônio com ela, e por seu intermédio, a obter o principado sobre aquela região. Ele, ainda, iludiu muitos judeus, de modo que eles acreditaram que ele fosse o seu messias.

Portanto, Maomé seduzia os povos, graças às suas astúcias, ao seu poder, à dilatação da lei concernente à prática do sexo e a um número considerável de promessas acerca da vida futura, e os compelia à sua perfídia graças à força de seu exército. De fato, mediante a lei dada por Maomé, os povos que ergueram suas as armas contra o Império, ao ocuparem determinadas regiões, obrigavam seus habitantes a abraçar a sua seita. Os que não a aceitavam, eram condenados à morte. Assim, da Arábia eles chegaram ao Egito e subverteram a população; dali

11 Heráclio, na verdade, temendo uma aliança dos monofisistas com os árabes, foi benevolente com os mesmos, e acabou professando uma outra heresia, o monotelismo, derivada daquela, segundo a qual, em Cristo só houve uma vontade e energia, a divina. 
passaram à África e fizeram a mesma coisa. Daquele lugar alcançaram a Espanha ${ }^{12}$ e obrigaram parte de sua gente a abandonar a fé primitiva. Foi deste modo que eles multiplicaram o número dos seus adeptos, antes usando a violência da guerra do que mediante a pregação da doutrina.

\section{Capitulo quinto}

Por conseguinte, morto Heráclio, e diminuído o poder do Império quanto ao domínio exercido sobre o Oriente, a sé imperial permaneceu na Grécia, em Constantinopla, até a época do imperador Constantino $\mathrm{VI}^{13}$ e de seu filho Leão, tendo sido governada por trinta e três imperadores, entre eles computado o próprio Constantino Magno, durante quatrocentos e cinqüenta e um anos e dois meses, neles incluídos os vinte e três anos do governo de Constantino.

Naquele tempo, à época do papa Leão III, ${ }^{14}$ de certo modo, começou a ocorrer a translação do Império dos gregos para os francos. Dado, porém, que, em geral, esta história, no tocante à origem ou ao princípio da mesma, não é corretamente sabida, face à variedade das informações passadas pelos seus narradores, convém, por isso, saber efetivamente e ressaltar com exatidão, que o fato que, a princípio, suscitou esta translação foi a discórdia ocorrida entre o imperador Leão $\mathbb{I I}^{15} \mathrm{e}$ a Igreja Romana, quanto à veneração das imagens. Com efeito, ele dizia que as imagens de Cristo e dos santos não deviam ser veneradas, porque isto lhe parecia uma espécie de idolatria. Mas Gregório III, ${ }^{16}$ que, então, governava a Igreja Romana, afirmava justamente o contrário.

$\mathrm{Na}$ verdade, o mencionado imperador Leão perseverando nesta sua crença, ao vir de Constantinopla a Roma, depois, trouxe consigo para Constantinopla ${ }^{17}$ todas as imagens de Cristo e dos santos que encontrou em Roma, e as tendo condenado mediante uma sentença, as queimou com fogo. Por isso, o citado pontífice Gregório III presumiu ter 0 direito de anatematizar o predito imperador Leão, e persuadiu toda a gente da Apúlia, da Itália e da Hespéria que se subtraissem de seu controle e obediência, em que, aliás foi bem sucedido, embora, tivesse agido de maneira ilegal, pois, ignoro, mediante por força de qual autoridade, oú melhor, audácia, podia ter feito tal coisa, e ademais, o proibiu solenemente de recolher impostos, e em seguida, reunindo um sinodo em Roma, confirmou a veneração das santas imagens e condenou com o anátema os transgressores de sua decisão.

$\mathrm{O}$ referido Leão finalmente morreu perseverando no antigo propósito. Sucedeu-lhe no governo seu filho Constantino V. ${ }^{18}$ Ele comungava da mesma idéia de seu pai. Como este imperador não ajudava a Igreja Romana em nada, o papa Estê-

12 Tarique e os bérberes islamisados transpuseram as Colunas de Hércules em 711.

13 Sucedeu o pai, Leão IV (775-780), ainda menor. A regência foi exercida por sua mãe, a basilissa, Irene, a qual o destronou e tomou o poder para si em 797 . Governou o império até 802, quando acabou sendo deposta por uma sublevação da nobreza, liderada por Nicéforo I, que governou 0 império até 811.

14 Dirigiu a Igreja de 795 a 816.

15 Imperador bizantino de 717 a 741 , em 726 decretou o inicio da iconoclastia.

16 Governou a Igreja de 731 a 741.

17 Não consta de nenhuma fonte da época, que esse fato tenha ocorrido.

18 Dirigiu o império bizantino de 741 a 775. 
vão $\mathrm{II}^{19}$ de certo modo ordenou transferir o Império Romano dos gregos para os francos, em vida de Pepino, ${ }^{20}$ rei dos Francos, o qual sobreviveu ao próprio pontífice. É por essa razão que algumas pessoas dizem que foi à época deste Estêvão que o Império foi transferido dos gregos para os francos, fato este, que, no entanto, deve ser entendido corretamente, isto é, que esta translação foi ordenada, não que a mesma tenha sido efetuada por ele. Portanto, à época deste papa Estêvão foi ordenada a translação do Império Romano para os francos, parte de quem os clérigos romanos já gozavam, sob muitos aspectos, de favores e benefícios.

\section{Capítulo sexto}

O mencionado Pepino, filho de Carlos Martel, ${ }^{21}$ era um valoroso homem na guerra, católico e preclaro pela honestidade de vida e hábitos. Conforme se lê nos escritos dos clérigos, os quais querendo usurpar para si próprios a autoridade alheia, consta que ele de mordomo do palácio foi elevado à mais excelsa dignidade do reino dos francos pelo papa Zacarias.

Como eles dizem, foi este Zacarias que depôs do trono Childerico, ${ }^{22}$ rei dos Francos, não tanto por causa das iniqüidades que havia cometido, mas porque, embora fosse um inútil, tinha muito poder, e o substituiu pelo predito Pepino, pai de Carlos Magno, e desligou todos os habitantes da Francia do juramento de fidelidade que the haviam prestado.

Mas Aimo [de Fleury] escreve na sua "gestis Francorum", e tal relato é o mais verdadeiro, que Pepino foi eleito legítimo rei pelos Francos e elevado a esta dignidade pelos próceres do reino, e que Bonifácio, arcebispo de Reims o ungiu em Soissons, no mosteiro de São Medardo.

Com referência a Childerico, o qual, antes, graças à condição de rei, vivia no ócio e estava amolecido pelos prazeres, foi obrigado a virar monge tonsurado. Daí, não ter sido aquele Zacarias que depôs Childerico do trono, mas como dizem certas pessoas, talvez, ele tenha concordado com a atitude tomada pelos que destituiram o monarca.

De fato, tal deposição do rei e a escolha de outrem como tal, ainda que seja por um motivo razoável, absolutamente não é da competência de um bispo ou de algum clérigo ou da corporação deles, mas, ao contrário, da alçada de todos os habitantes da região, cidadãos e nobres ou da parte mais importante da multidão, conforme o demonstramos em nosso Defensor da Paz, primeira parte, capítulos $13^{\circ}, 14^{\circ}, 15^{\circ}$ e $18^{\circ}$. É por essa razão que devemos acolher o relato de Aimo como verdadeiro, e recusar os textos dos clérigos sobre este assunto, posto que são falsos e prejudiciais aos Francos.

19 Governou a Igreja de 752 a 757.

20 Governou os francos, como rei, de 751 a 768. Desde 741, até aquela ocasião, exerceu o cargo de mordomo do palácio, herdando-o de seu pai, Carlos Martel.

21 Mordomo do palácio dos reinos merovíngios, os quais conseguiu unificar sob a sua tutela, exerceu este cargo de 714 até 741, quando faleceu. Em 732, na batalha de Poitiers derrotou os islâmicos e os rechaçou para o sul dos Pirineus, impedindo-os de ampliar seus dominios em território cristão.

22 último rei franco da dinastia merovingia. Governou de 742 a 751 . É o que traz explicitamente o Decreto na distinção XV, questão 6, no capítulo Alius. 
Ora, com vista a ficar mais evidente, porque, por qual motivo e de que modo foi feita a mencionada translação do Império dos gregos para os francos, prosseguiremos narrando brevemente a história do referido Pepino rei da Francia e da Germânia.

\section{Capítulo sétimo}

Portanto, morto o papa Zacarias, que concordara com a ascensão de Pepino à realeza, embora, conforme alguns, ele tenha sido legitimo rei dos francos independentemente de seu assentimento, como o dissemos antes, no ano do Senhor de 778 e no ano de 1530 da fundação da Cidade, Estêvão II, romano de nascimento, através de seu pai, Constantino, foi elevado ao sumo pontificado. Ora, de acordo com o que Aimo escreveu no livro $\mathrm{V}$ das Gestas dos Francos, àquela época, Estêvão II, oprimido por Astolfo, rei dos Lombardos ${ }^{23}$ dirigiu-se à Francia, ${ }^{24}$ para junto do rei Pepino, com o propósito de recuperar os bens temporais da Igreja Romana, a qual fora espoliada dos mesmos pelo predito Astolfo.

O rei Pepino foi apropriadamente ao encontro do papa romano, a três milhas de distância de seu palácio real, e depois, com as honras devidas, o conduziu até o mesmo. Então, o mencionado papa expôs cuidadosamente o motivo que o levou a dirigir-se até ao rei, narrando-lhe em detalhes as injúrias que Astolfo lhe havia infligido.

O rei, querendo o servir e satisfazer-lhe a vontade, preparou um grande exército e junto com o referido pontífice marchou para a Itália, a fim de combater Astolfo, o qual, negando-se a restituir os referidos bens temporais à Igreja Romana, igualmente se organizou, com todas as suas forças, para resistir ao mencionado Pepino. Houve, pois, uma batalha entre ambos, na qual Astolfo foi vencido juntamente com os seus aliados, de modo que, em seguida, foi compelido a restituir à Igreja Romana os seus bens temporais. Ele, então, entregou quarenta reféns escolhidos dentre os melhores de seu reino à mencionada Igreja Romana, e sob juramento, prometeu restituir-lhe os seus bens temporais.

Depois destes acontecimentos, o vitorioso rei Pepino regressou contente à Francia e o papa Estêvão retornou à Sé Apostólica, em Roma. Todavia, o referido Astolfo não cumpriu com nada do que havia prometido a Pepino, pelo que ele teve de retornar à Lombardia para lutar contra Astolfo, sitiando-o em Pavia. ${ }^{25}$ Ele, então, o coagiu a cumprir com o que prometera.

Em seguida, o mencionado Pepino invadiu Ravena e a conquistou, bem como submeteu vitoriosamente a Pentápole da Romaníla com o Exarcado, onde se encontra Bolonha, e conforme está escrito, doou de fato todo esse território à Igreja Romana. ${ }^{26}$

23 Governou esse povo de 749 a 756.

$24 \mathrm{O}$ encontro entre ambos ocorreu em Porthion em janeiro de 754. Nessa altura, o papa consagrou novamente Pepino, bem como seus filhos Carlomano e Carlos, e lhes conferiu o título de Patricio dos romanos. Martinho Polonês, seguindo a glosa do canonista Bernardo de Pavia, ao capítulo Venerabilem (Inccêncio III), op. cit.,: 426, diz o seguinte: [Estêvão II] "uitimo anno sui pontificatus imperium in personam magnifici regis Karoli tunc in iuvenili aetate constituti transtulisse".

26 Trata-se, como se sabe, dos territćrios que originalmente constituíram o Patrimonium Petri. 
O predito papa Estêvão, a fim de que pudesse dominar mais livremente a Itália, seduzido por todos esses benefícios, e considerando a imbecilidade do imperador daquela ocasião e a pressão que os Gregos estavam a sofrer, e que os gauleses absolutamente não estavam preocupados com tais coisas, empenhando-se em transferir o Império para uma nação estrangeira e longínqua, com a ajuda de seus partidários, procurou, então, transferi-lo dos gregos para os francos, não tendo se lembrado nem um pouco dos benefícios que os imperadores haviam concedido à Igreja Romana.

Portanto, é assim que devem ser entendidos todos os escritos que dizem que, no tempo do papa Estêvão, o Império foi transferido dos gregos para os francos, isto é, que em sua época, a translação foi ordenada, pois, na verdade, foi durante o pontificado de um outro papa, a saber, de Leão III, que tal transferência foi efetivamente consumada, conforme adiante ficará evidente, a partir do que irá ser relatado.

\section{Capítulo oitavo}

A Igreja Romana, à morte do papa Estêvão II, encontrava-se sob a proteção de Pepino, o qual, após 18 anos de reinado, tendo ingressado neste caminho pelo qual passa toda a natureza humana, também partiu deste mundo, sendo substituido no trono por seu filho Carlos, ${ }^{27}$ designado Magno, por causa da grandeza de suas virtudes. Neste tempo, três pontifices, a saber, Paulo I, Constantino II e Estêvão III sucederam um ao outro, cujas eleições e vidas, omito tratar aqui, com o propósito de abreviar o assunto.

No ano do Cristo Nosso Senhor de 795 e no ano de 1547 da fundação da Cidade, Adriano I, ${ }^{28}$ romano de nascimento, da parte de seu pai Teodoro, natural do bairro Via Lata, foi eleito sumo pontífice, o qual governou a Igreja Romana durante 23 anos, 10 meses e 18 dias.

Este pontífice implorou o auxilio de Carlos Magno, que, então, governava os reinos da Francia e da Germânia, em favor da Igreja Romana contra os lombardos. ${ }^{29}$

Com efeito, morto Astolfo, rei dos lombardos, sobre o qual falamos antes, sucedeu no trono, seu filho Desidério, ${ }^{30}$ o qual, seguindo o caminho de seu pai, privou a Igreja Romana de seus bens temporais e de outras possessões que lhe pertenciam, a saber, vilas, cidades e demais praças fortes, bem como passou a oprimir os romanos, cobrando-lhes tributos e outros impostos. Foi por este motivo que Adriano erviou à Francia um legado, Pedro, cardeal presbitero, ao supradito Carlos, implorando-lhe uma ajuda contra o mencionado Desidério.

Este príncipe recebeu favoravelmente o legado, e depois, tendo reunido uma assembléia de próceres e prelados, julgou oportuno anuir às súplicas de Adriano.

27 Rei dos francos desde 768.

28 Governou a Igreja de 772 a 795 .

29 Tal solicitação ocorreu no transcurso de 772 .

30 Desidério não era filho nem parente de Astolfo. Anteriormente fora duque da Toscana. Governou os lombardos de 757-774. 
Obtido o favor esperado, o referido legado voltou. O rei, então, preparou um numeroso exército e o conduziu por mar e através das montanhas até a Lombardia, tendo encontrado algumas dificuldades para fazer isso.

Chegando, pois, à Ligúria e à Emilia, regiōes que agora são designadas por planícies da Lombardia, Carlos fixou suas tendas e dispôs seu acampamento ao redor de Pavia, e aí celebrou o natal do Senhor, de acordo com os relatos históricos.

Enfim, Carlos, tendo deixado seu exército acampado, e sendo levado pela devoção, partiu para Roma, e aí, juntamente com o predito Adriano, passou o domingo de Páscoa, ${ }^{31} \mathrm{e}$, uma vez celebrada a solenidade pascal, regressou ao acampamento militar fixado ao redor de Pavia. Depois, tendo prosseguido em seu cerco e combatendo, conquistou a cidade. Em seguida, aprisionou Desidério, rei dos lombardos, juntamente com sua mulher e seus filhos, o qual, com os seus, submeteu-se ao seu poder ${ }^{32}$ Ali, também compareceram todos os embaixadores e núncios de cada uma das cidades da Itália, e igualmente se sujeitaram ao domínio do rei Carlos. Livre desses fazeres, realizados com sucesso, ele, tornando a regressar a Roma, restituiu os bens temporais à Igreja Romana e simultaneamente, de fato, doou-lhe, por causa de sua liberalidade, os ducados de Espoleto e de Benevento.

Então, o mencionado pontífice Adriano seduzido por aqueles benefícios temporais ofertados pelo referido príncipe, reuniu um concílio em Roma, em que compareceram 153 bispos e abades, e durante o mesmo, juntamente com eles, conferiu ao glonioso príncipe Carlos o direito e o poder de eleger o sumo pontifice ${ }^{33}$ e de colocar em ordem a Sé Apostólica; concedeu-lhe também a dignidade de Patrício, cujo título, outrora, quase equivalia a ser considerado como pai do príncipe. Além disso, ele decretou que os bispos e os arcebispos de cada provincia eclesiástica deviam receber a investidura de Carlos, e a fim de que ninguém viesse a consagrar um bispo, caso este não tivesse sido investido e nomeado pelo rei, amaldiçoou com o anátema todos aqueles que procedessem contra aquelas determinações, e a menos que voltassem atrás, ordenou, ainda, que todos os bens dos recalcitrantes fossem confiscados. Todavia, o referido pontífice, como um outro bispo ou clérigo, não tinha nenhuma autoridade para fazer isso ou conceder tais coisas, salvo se, talvez, tivesse recebido uma ordem e delegação do povo romano para tanto.

Entretanto, Carlos, de honrosa memória, não usou da primeira concessão, isto é, do poder de eleger o sumo pontifice e de colocar em ordem a Sé Apostólica, talvez, pelo fato de, a partir do momento da predita concessão, terem havido poucos sumos pontifices, durante o seu governo que perdurou por um período de quarenta anos. Com efeito, no aludido espaço de tempo, apenas o mencionado Adriano e Leão III presidiram a Igreja Romana, cujos pontificados duraram quarenta e quatro anos e alguns meses. Não há, porém, nenhum documento que

31 A festa da Páscoa, naquele ano, ocorreu em 3 de abril.

32 Carlos Magno venceu definitivamente Desidério, nos primeiros dias de junho de 774. Desde então também passou a usar o titulo de rex longobardorum, tendo acrescentado o território lombardo aos seus dominios.

33 É o que traz o Decreto na distinção LXIII, nos capitulos Adrianus e In synodo. 
afirme que o próprio Carlos não gozava de tal direito que lhe havia sido concedido, mediante a citada doação, nem tampouco que a tivesse cedido a outrem. No entanto, com referência à segunda concessão, isto é, a concernente à designação dos bispos, ele a utilizou, como aparece em muitos lugares de suas gestas. Contudo, consta que Ludovico [O Piedoso] ${ }^{34}$ renunciou a tais direitos que lhe competiam. Mas, a fim de prosseguirmos mais rapidamente em nosso propósito respeitante à transferência do Império, omitiremos narrar muitos fatos realizados por Carlos que comprovam a sua magnificência.

\section{Capitulo nono}

Morto o mencionado Adriano, reinando Carlos Magno, protetor da Igreja Romana, Leão III, romano de nascimento, da parte de seu pai Astolfo, foi elevado ao sumo pontificado. Porém, no ano de 819 e no ano de 1571 da fundação da Cidade, este pontífice, durante uma das procissões das Rogações foi capturado em Roma, ${ }^{35}$ cegado e teve a sua língua cortada. Colocado na prisão, entretanto, ele conseguiu se evadir dela pelo muro, e com enorme confiança, fugiu para junto dos legados do mencionado Carlos, a saber, o abade Guiraldo e Vingísio, duque de Espoleto.

Este pontífice, em consonância com o que Ricardo narra em sua crônica e com o que também relatam outras histórias, uma vez que não há qualquer menção a respeito de sua vida, no tocante a que a mesma fosse ilibada, como o descrevem as histórias, e quem o quiser pode acreditar, teve, mediante a graça divina, plenamente restituídos os seus membros, a saber, os olhos e a língua, e se dirigiu à Francia, para junto de Carlos, protetor precipuo da Igreja, o qual o recebeu, como era devido, com honra, e viajando com ele para Roma, ${ }^{36}$ através da aplicação da justiça, reparou a injúria que lhe havia sido feita bem como à Igreja Romana.

Aimo, descrevendo estes fatos mais detalhadamente, na sua "Gestis Francorum", diz que depois que o rei se aproximou do lugar chamado Mentana, localizado a doze marcos miliários de Roma, o papa Leão, que o precedera, com uma grande comitiva dirigiu-se ao seu encontro, e dado que ele era Patrício da Cidade, o recebeu humildemente e com toda a honra devida, e como o relatam as histórias, naquele predito lugar, tomou a refeição com ele.

Em seguida, imediatamente, o mencionado papa e sua comitiva regressaram a Roma à frente do rei. No dia seguinte, o pontifice também fez o mesmo, esperando-o nos degraus da basílica do Bem-aventurado Pedro apóstolo. Então, os estandartes da Cidade foram enviados ao rei, e os grupos, tanto de cidadãos quanto de peregrinos, postados em ordem, nos lugares apropriados, foram conclamados a cantar as Laudes para o receber. Após o rei apear do cavalo e começar a subir as escadarias da igreja, o papa, o clero e os bispos o receberam e Leão proferiu um discurso. A seguir, o introduziu na basilica, enquanto todos salmodiavam. Este fato ocorreu no trigésimo terceiro ano de seu reinado.

34 Filho e sucessor de Carlos Magno, governou o império de 814 a 840.

35 O atentado contra Leão III ocorreu em 25 de abril de 799. Cfr. Martinho Polonês, op. cit.: 461.

36 Na verdade, Leão III regressou a Roma, no transcurso do outono. Carlos chegou mais tarde, em 24 de novembro de 800 . 
Passados sete dias, o rei, tendo convocado uma assembléia, anunciou o motivo porque viera a Roma, e desde então, èle se dedicou quotidianamente a fazer aquilo que o trouxera à Cidade ${ }^{37}$ Embora, graves acusações tivessem sido proferidas contra Leão, posto que não foi encontrado ninguém que apresentasse provas fidedignas a respeito, o próprio sumo pontífice, com a anuência do rei, e perante todo o povo, levando os Evangelhos pela basílica do Bem-aventurado Pedro subiu ao ambão, e tendo sido invocada a Santíssima Trindade, ele, mediante um juramento, se eximiu canonicamente dos crimes que lhe imputavam. ${ }^{38}$

Mas outras histórias acrescentam, ainda, que três cardeais, pondo as mãos sobre os santos Evangelhos de Deus, afirmaram que tudo o que diziam do sumo pontífice era falso. Esta purificação foi solenemente aprovada por todo o clero e o povo, e legitimamente confirmada pelo príncipe.

No mesmo dia, como escreve Aimo em sua "gestis Francorum", um certo abade chamado Zacarias e outros dois monges, um da abadia localizada junto do monte das Oliveiras e o outro do mosteiro de Santo Sabá no Oriente, chegaram a Roma, convidados que foram pelo patriarca de Jerusalém. Eles traziam consigo as chaves daquela cidade, do sepulcro do Senhor, e do Calvário bem como um estandarte. Carlos, tendo-os recebido com benevolência, os reteve consigo durante alguns dias, e tendo-lhes prestado as honras devidas, os tratou com muita consideração. Alguns dias depois, ele os reenviou à Palestina, oferecendo-lhes presentes e dons magníficos, dignos da majestade real.

Algumas histórias trazem, que o rei, comovido com aquela legação, face à solicitação de Constantino VI, então imperador, juntamente com um poderoso exército, fez a travessia maritima e recuperou toda a Terra Santa, com a anuência do rei dos persas, que àquela aitura, reinava sobre a Palestina e toda a Síria. Na verdade, a fama do célebre e glorioso rei Carlos também já percorria todo o Oriente, de modo que o mencionado rei dos persas, ${ }^{39}$ que governava no Oriente, desejava gozar de sua benevolência, por isso, enviou-lhe presentes magnificos, através de legados e núncios oficiais.

O predito rei Carlos, vitorioso por toda a parte, recuperada a Terra Santa, passou por Constantinopla regressando a Roma, e aí, junto com o papa Leão, celebrou solenemente o natal do Senhor.

Neste mesmo dia sacratíssimo do nascimento de Cristo, durante a missa celebrada no altar consagrado ao Bem-aventurado Pedro, quando o gloriosissimo rei Carlos erguia-se, após ter orado com devoção, o papa, Leão tendo preestabelecido cerimonialmente todas as coisas necessárias à tamanha solenidade, colocou a coroa imperial sobre a sua cabeça e ele foi aclamado por todo o povo romano: a Carlos Augusto, magno e pacífico imperador, coroado por Deus, que lhe sejam asseguradas do céu a vida e a vitória.

37 Este fato ocorreu em $1^{2}$ de dezembro de 800.

38 Este acontecimento ocorreu no dia 23 de dezembro de 800 .

39 Trata-se, de fato, de Harum al-Raschid (786-809), califa abássida de Bagdá, cujos dominios se estendiam desde o atual Iraque sobre o Egito, Palestina e Síria. Foi com ele que Carios Magno manteve relações diplomáticas. 
Todas as histórias narram esta coroação imperial efetuada peì papa Leão e a aclamação, com os louvores imperiais, feita pelo povo. Mas, em seguida às mesmas, conforme 0 antigo ritual de entronização dos principes, Carlos foi adorado por todos, e tendo renunciado ao título de Patrício, foi aclamado Imperador Augusto pelos presentes.

O predito Carlos governou o Império Romano durante quatorze anos. Ele também já governava os reinos da Francia e da Germânia há trinta e três anos, durante os quais, conforme os relatos históricos, fora designado por rei e Patrício, mas em seguida à coroação imperial, desde aquele ano, todos os anais, todas a gestas e histórias que fazem menção a seu respeito, sem que haja qualquer discordância entre os relatos, o chamam de Imperador Augusto.

Com referência à legitimidade, ao direito e à validade que esta transferência do Império teve, feita àquela altura, tal assunto está claro e igualmente o ficará para todos quantos vierem a ler o último capítulo de nosso Defensor da Paz.

A mencionada transferência do Império dos gregos para os francos durou sete gerações, quer dizer, prolongou-se durante o reinado de sete imperadores, permanecendo mais de centro e três anos com eles.

\section{Capítulo décimo}

O imperador Arnulfo, o último da estirpe do mencionado Carlos, era vil e efeminado. Ele foi medroso e negligente contra o tirano Berengário ${ }^{40}$ que, então, combatia a Igreja Romana na Itália, e igualmente contra outros, que a afligiam em muitos lugares. Ademais, como o relatam Martinho Polonês e Tuscêncio, ele próprio, àquela altura, também perseguia a Igreja Romana.

Toda a estirpe de Carlos, à frente do Império, terminou completamente, quando o filho ${ }^{41}$ do mencionado Arnulfo, antes de receber a bênção imperial, foi vencido e mutilado próximo de Verona pelo predito tirano Berengário, o qual começou a dominar sobre a Itália, e a partir daquela ocasião, a Igreja Romana começou a periclitar por causa de perseguições freqüentes de que sofria. Então, como relata Sicardo, bispo de Cremona, um dos maiores historiadores, posto que o mencionado tirano atormentava a própria Igreja, e porque ela era governada por um mercenário, não por um verdadeiro pastor, a saber, João ${ }^{42}$, filho de $A l b e r i c 0^{43}$, os cardeais, de comum acordo, no ano do nascimento do Senhor de 950, escreveram ao duque da Saxônia [Otão] o qual era um homem muito poderoso, e àquela época,

40 Marquês de Ivréia, em 950 fez-se coroar rei da Itália juntamente com seu filho Alberto ou Adalberto.

41 Chamava-se Ludovico. Quem relata esses fatos é Martinho Polonês, op. cit.: 463, 465. Sicardo diz que os cardeais enviaram embaixadores ao rei Otão, pedindo-lhe socorro, o qual, desde 936 era rei da Alemanha.

42 Décimo segundo papa com este nome, governou a Igreja de 955 a 963. Em 2/2/962 sagrou Otão I Imperador. Cfr. Martinho Polonês, op. cit.: 465.

43 Trata-se de Alberico o jovem, homônimo de seu pai. Govemou Roma e os ducados da Toscana e de Espoleto desde 932 até 954, quando faleceu. Em 951 conseguiu deter Otāo e seu exército, que, após ter conquistado a Lombardia, governada por Berengário, pretendia igualmente submeter a Itália central e Roma, tendo sido obrigado a regressar à Alemanha e deixara a Lombardia a Berengário. 
governava toda a Alemanha. Ele também era católico fervoroso, previdente ao aconselhar, justo ao julgar, fiel no cumprimento dos deveres que the competiam, corajoso na guerra e notável pela honestidade de seus costumes, e ainda, totalmente devotado para com a Igreja de Deus.

Foi, pois, a este príncipe que os cardeais imploraram o auxilio, para que protegesse e ajudasse a Igreja Romana, a qual periclitava por causa das muitas procelas que se abatiam sobre ela. Ele preparou um grande exército, transpôs os Alpes, veio à Itália e guerreou com o antes mencionado Berengário, ${ }^{44}$ e tendo-o derrotado juntamente com seu exército, o matou.

Em seguida, dirigindo-se a Roma, aí reuniu um concilio dos cardeais, e por conselho dos mesmos, dado que o papa era incorrigivel, o advertiu para que renunciasse ao papado, mas como obstinadamente não quisesse fazer isso, ele, recorrendo à força, o aprisionou no castelo de Santo Ângelo, obrigando-o a renunciar. ${ }^{45}$

Então, Leão VIII ${ }^{46}$ foi estabelecido pastor da Igreja Romana, o qual, seduzido pelos beneficios concedidos à mesma pelo predito Otão, tanto porque ele a livrara de Berengário que a perseguia, quanto por causa da reforma da mencionada Igreja que ele fizera, concedeu-lhe os mesmos direitos que Adriano havia dado a Carlos. Em seguida, realizou um sínodo, tendo reunido o clero e o povo romano, os quais, o constituiram imperador, sem que antes tivesse havido uma eleição, a qual, [para tanto] foi instituída, quarenta anos mais tarde. Assim foi feita a translação do Império dos francos ou gauleses para os germânicos.

Otão I, mediante esse procedimento, obteve pacificamente o Império. Também o possuiram sucessivamente, sem que tivesse havido nenhuma oposição, seu filho [Otão II] e seu neto [Otão III] ${ }^{47}$

\section{Capitulo undécimo}

Depois destes acontecimentos, morto Otão III sem ter tido filhos, Gregório V,48 da nação teutônica, parente de Otão, assumiu o sumo pontificado. Foi à sua época, como o relata Martinho Polonês, que foram estabelecidos os eleitores do imperador, a saber, sete príncipes alemães, quatro laicos e três clérigos ou prelados. ${ }^{49}$

44 Otăo derrotou novamente Berengánio no outono de 961, tornando-se rei da Lombardia.

45 Esses eventos ocorreram, na verdade, em novembro/dezembro de 963, quando Otão I teve de regressar novamente a Roma, porque João XII e seus partidários (Berengário) se rebelaram contra o seu sucessor. Governou a Igreja de 963 a 965. Estes imperadores governaram respectivamente de 973 a 983 e 983 a 1002.

48 Dirigiu a Igreja de 996 a 999. Em 21 de maio de 996, logo após sua eleição, coroou Otão III imperador.

49 Martinho Polonês nâo faz essa afirmação em sua Chronica Suas plavras, op. cit:: 46€, são as seguintes: "et licet isti tres Ottones per successionem generis regnaverint, post tamen institutum fuit, ut per officiales imperii imperator eligeretur, qui sunt septem...". Ptolomeu de Lucca O.P. (1236-1326/7) a menciona por três vezes, a saber, na Determinatio Compendiosa, escrita em 1280 ou pouco depois, ed. cit., cap. XII, p. 29, Cfr. M. Krammer, Praefatio, IX, no De regimine principum III, 19 (c. 1300), e no Tractatus de origine ac translacione et statu romani imperii, ed. cit., p. 72 , atribuindo tal ato ao próprio Gregório V, como poderá adiante ser verificado no Apêndice II. 
Ora, os três últimos preditos imperadores obtiveram sucessivamente o Império como se fosse quase um direito hereditário. Todavia, para o bom estado da Igreja de Deus e do povo cristão, foi útil e prudentemente ordenado que um poder tão excelso não mais fosse atribuido a alguém por força do direito de sucessão hereditária, mas sim, mediante a virtude, e que se procedesse a uma eleição, a fim de que o mais digno viesse a possuir o titulo para governar o Império.

Portanto, foi estabelecido que sete próceres oficiais do Império passassem a eleger o rei dos Romanos, o qual, depois, seria coroado pelo romano pontífice com a coroa imperial. Como anteriormente foi dito, os sete são três preiadios, que eram e ainda são chanceleres do Império, nomeadamente, o arcebispo de Colônia, chanceler da Itália, o arcebispo de Tréves, chanceler da Gália, e o arcebispo de Mogúncia, o chanceler da Germânia, e quatro barões, que serviam e servem o imperador Romano, a saber, o marquês de Brandemburgo, o duque da Saxônia, o duque da Baviera e o rei da Boêmia. Daí o teor do seguinte verso: [os arcebispos] de Mogúncia, de Tréves e de Colônia, cada um deles é chanceler do Império. O conde Palatino é o escudeiro, o duque leva a espada, o marquês é o camareiro mor e o rei da Boêmia é o copeiro. Eles todos escolhem o senhor supremo através dos séculos.

Esta disposição foi tomada no ano de 1004, como o demonstram claramente as gestas dos germânicos.

\section{Capítulo duodécimo}

Portanto, de tudo o que foi precedentemente escrito, fica evidente ợe no tempo do rei Pepino e do papa romano Estêvão foi estabelecida a translação do Império Romano dos gregos para os francos, face às circunstâncias anteriormente referidas. À época de Adriano I, Carlos Magno foi estabelecido como Patrício da Urbe, protetor da Igreja Romana e eleitor do Romano Pontífice. No tempo de Leão III, muitas vezes referido, Carlos Magno foi estabelecido Imperador Romano, e ainda, àquela época, foi efetivamente reaiizada a translação do Império dos principes gregos para os francos.

Enfim, com o passar do tempo, depois de transcorridos muitos anos, conforme relatamos, no tempo do papa romano Leão VIII, foi efetuada a translação do Império dos príncipes francos ou gauleses para os germânicos.

Em seguida, à época de Gregório V, foi instituída a eleição do Imperador Romano, a ser efetuada pelos sete mencionados principes da Alemanha, os quais desde então, até aos nossos dias, elegem o Imperador, que deve ser coroado pelo bispo romano, embora, não haja motivo algum que justifique a necessidade de esta coroação ser efetuada por ele.

Logo, o Império Romano foi transferido desse modo para os teutônicos ou germânicos.

Por conseguinte, tudo o que dissemos, foi tentado pelos bispos romanos e com o assentimento dos mesmos, no entanto, quanta força tinham ou ainda a têm para fazer isso, o mostramos claramente, a quem quiser verificar usando da razão, na primeira parte de nosso Defensor da Paz, capítulos $12^{\circ}$ e $13^{\circ}$, e na segunda parte do mesmo, no último capítulo.

Termina o tratado sobre a translação do Império. 


\section{Apêndice II}

Pág. 67

“...Romanum imperium Rome sine mutatione permansit per XXX et III imperatores et CCC et LIII anos vel V menses, computando ab Octaviano Augusto, Romanorum imperatore, iuxta ystorie veritatem usque ad tempora magni Constantini, sciendum est, quod predictus Constantinus septimo anno sui imperii sedem imperialem mutavit transíerens ipsam in Bizancium civitatem, que nunc Constantinopolis appellatur...".

“...pacifice usque ad XX. Annum imperatoris Eracli... omnes orientalis populi a Latinorum dominio... recesserunt.

Pág. 68

"Mortus Eracleo et quantum ad dominium orientis, remansit imperialis sedis in Graecia apud Constantinopolim usque ad tempora Constantini V vel Leonis filii sui per XXXIII imperatores, computato magno Constantino predicto, et per quadringentos LVII. Annos et XXI menses, computatis viginti tribus annis de imperio Constantini... Nam de Romam in Graeciam supervixit".

“...de Constantinopoii Romam veniens, omnes Christi et sanctorum ymagines... cremavit...".

“...Pipinus... predictus Caroli Marteli filius, vir in rebus bellicis strenuus... catholicus et... honestate preclarus... de maiore domus in rege Francorum excellenciam extitit sublimatus de quo legitur et narratur XV. q. VI c. Alius...”.

"...Mortuo Zacaria papa... Stephanus I, nacione Romanus, in summum pontificium sublimatus... venit in Franciam ad Pipinum pro iustitia sancti Petri recuperanda...".

Pág. 69

“...post XVIII annum regni sui, [viam] universe carnis ingressus... a virtutum magnitude dictus est magnus... tribus pontificibus, videlicet Paulo primo, Constantino et Stephano II [I] , intermediis, Adrianus I, nacione romanus, anno Domini VIICLXXI vel ab Urbe condita millesimo VCXLII in summum pontificem electus...".

“...mortuo Adriano predicto, regnante Karoli Magno, ecclesiae defensore, Leo III], nacione Romanus, ex patre Astulpho, in Romanum pontificem sublimatur anno Domini VII [I]CXVI vel ab urbe condita M[D]LXXV. Et in letania maiori captus Rome cecatus est et lingua detruncatus, sed restitutis sibi plenarie membris, scilicet, oculis et lingua, divina virtute...".

Pág. 70

“...Ad predictum Karolum venit in Franciam tanquam ad precipuum ecclesiae protectorem, qui... est decuit eum omni reverencia et honore suscepit, et cum ipso Romam accedens, iniuriam dicti pontificis et sancte Dei ecclesiae ultus est iusticia mediante...”.

“...ipsa siquidem die nativitatis Domini, cum idem Karoius gloriosus in missa ante altare beati Petri surgeret $\mathrm{ab}$ oratione devota, preordinatis omnibus ad tantam sollenitatem necessariis, coronam imperialem capiti eius imposuit vel a cuncto populo Romano acclamatum est: Karolo Augusto a Domino coronato magno et pacifico imperatori vita et victoria de caelo subministret... more antiquorum principum fuit ab omnibus appellatus... XXIII annis... duravit vero huiusmodi imperii per ecclesiam facta translacio de Grecis in Francos per VII generaciones, videlicet, per VII imperatores, annnis centum tribus et amplius...".

Pág. 71

“...inperator Arnulphus, ultimo de genere Karcli antedicti effeminatus et vilis fuit... remissus vel thepidus contra Berengarium tirannum, qui tunc in Italiam Dei ecclesiam impugnabat et alios qui ipsam in multis partibus molestabant... ipsemet erat ipsius ecclesiae persecutor...".

"...filio Arnulphi predicti, çui nondum imperialem benedictionem habuerat, devicto a predicto Berengaric... cepit dictus Berengarius tirannus in Ytalia dominari et ecclesia persecucionibus urgentibus vacillare, cum quia dictus tyrannus ecclesiam eum molestabat, tum quia ecclesie non verus pastor, sed mercenarius preherat, scilicet, Ioannes, filius Alberici, et idcirco prcout tradit Sicardus cremonensis, episcopus, magnus ystoriarum scriptor, cardinalibus tunc de communi concordia scripserunt Ottoni duci Saxoniae, qui fuit vir magne potentie - nam in tota Saxonia dominabatur... erga 
sanctam Romanam Ecclesiam - ut ecclesiam Dei que procellis impellentibus vacillabat, protegeret atque eciam adiuvaret...”.

“...eandem dignitates eidem Ottoni concessit quas Karolus contulerat Adrianus insuper ipsum imperatorem constituit nulla precedente ellectione, quae postea a XL annis fuit instituta... et sic facta est translacio imperii de Gallicis in Germanos...".

Pàg. 72

“...Post hec mortuo Ottone III], sine filiis, Gregorius V, nacione Theutonicus de Saxonia de parentella Ottonis, prius Bruno vocatus, in summum pontificium assumitur, cuius pontificis tempore vel per ipsum pro bono statu ecclesie et populi christiani est provide ac utiliter ordinatum, ut tante sublimitatis, videlicet, imperialis, ordinacio, que non debet[ur] sanguine, sed virtute, non per viam successionis, sed electionis procedat... per principes, officiales imperii, qui regem Romanorum eligerent per Romanum pontificum confirmandum vel imperiali diademate coronandum, videlicet, per tres prelatos, qui erant vel... IIItor barones... Hec autem ordinacio facta anno millesimo quarto, ut Gesta Germaniae et cronice Martiniane vel aliae magnifeste declarant.....

\section{De Translatione imperii (Landolfo Colonna)}

Cap. I, pág. 89

“...Et vsque ad Constantinum magnum, triginta tres Imperatores \& quatuor Caesares numerantur, qui Romani sedem tenuere imperii.Constantinus magnus septimo anno regni sui imperii, sedem mutauit imperii, ipsam in Orientem transferens, ad Bizantium ciuitatem, quae nunc Constantinopolis est vocata, \& secundum imperialia iura Romae veteris praerogativa laetatur. Et ibi sedem imperialem constituit, contentus dominio Orientis. Occidentem vero, scilicet Romam \& totam italiam, \& omnia occidentalia regna cum omnibus dignitatibus imperialibus, beato Sylvestro tunc Romano Pontifici, eiusque successoribus libere disponere concessit: indignun iudicans religiosus Imperator, ibi terrenum Imperatorem dignitatem \& potestatem habere, ubi coelestis Imperatoris vicarius morabatur. Hoc plane legitur 1. q. Distinct. l. Constantinus...".

\section{Cap. II, pág. 89-90}

"Tenuit quoque Constantinus, eiusque sucessores Imperatores Romani, pacife dominium Orientis, vsque ad vigesimum annum Imperatoris Heracli, tunc omnes populi orientales a dominio Latinorum vniversaliter recesserunt. Sed causa, propter quam recesserunt, \& modus, per quem, communiter ignoratur... Causa siquidem, quare orientales iam dicti a dominio Imperii recesserunt, fuit tyrannicus principatus huius Heraclii...".

\section{Cap. III, pág. 91}

"Heraclio igitur mortuo, \& imperii sic difformata potentia, quantum ad dominium Orientis, remansit Imperialis sedes in Graecia apud Constantinopolim, usque ad tempora Constantini sexti, \& Leonis filii sui, per triginta tres Imperatores: computato Magno Constantino, per quadringentos quinquaginta vnum annos \& vndecim menses: computatis viginti tribus annis, de imperio Constantini, quos post translatam seu mutatam sedem de Roma in Graeciam superuixit. Tunc Leo Papa tertius, imperium de Graecis in Francos transtulit, in persona magnifici principis Caroli, magni Franciae ac Germaniae regis. Sed quia haec historia propter scriptorum varietatem communiter est ignota, ipsam proviribus declarabo... translationem Imperii de Graecis in Francos, \& de Francis in Germanos veraciter \& sine contradictionem describam. Attendendum est igitur diligenter \& principium \& causa huius translationis fuit, discordia inter Sacram Romanam Ecclesiam \& Imperatorem Leonem, propter venerationem sanctarum imaginum... Et successit ei in Imperio Constantino quintus magis impius, non solum in errores praedictos, sed etiam in omnibus vitiis \& peccatis... in quibus longo tempore superuixit... et quia hic pessimus, Imperator, in nullo iuuabat ecclesiam, imo tanquam haereticus potius offendebat, Papa Stephanus secundus, vitimo anno sui Pontificatus, Imperium transtulit de Graecis in Francos; sicut habetur Extr. de elect. c. Venerabilem...".

Cap. IV, pág. 91

"Is siquidem Pipinus Caroli Martelli filius, vir in rebus bellicis strenuus, religione catholicus, \& vniversa morum honestate praeclarus, a Zacharia Papa ad Maioris domus Francorum excellentiam extitit sublimatus, qui quidem Zacharias, regem Francorum Hildericum non tam pro suis iniquitatibus 
quam pro eo quod tantae potestatis erat inutilis, a regno deposuit \& praedictum Pipinum Caroli magni patrem in eius loco substituit: omnesque Francigenas a iuramento fidelitatis, quo dicto Hilderico tenebantur, absoluit, ut 15 q. 6 alius. Sed Annonius in gestis Francorum scribit, Pipinum per Francos legitime fuisse electum in Regem \& et protectorem elevatum, \& per Bonifacium archiepiscopum Remensem vnctum Suessioni, id est, in tali loco, in monasterio sancti Medardi. Hildericus vero, qui tunc sub nomime regio, in deliciis marcebat ocio in monachum consecratus est. Hic ergo vebum Deposuit, positum in dicto capitulo, alius glosauit, id est, Deponentibus consensit. Sed qualitercunque dicatur, siue ut praedicta Francorum narrat historia, siue ut alius supra allegatus, salua semper in omnibus veritate: credo authoritatem Papae in talibus omnibus negociis praesupponi, ex eo quod omnis potestas ex eo in hoc dependet, vt Papam Gelasium Imperatori Anastasio legimus rescripsisse \& vt clarius patebit...".

Cap. V, pág. 92

“...Mortuo igitur Zacharia Papa, qui Pipinum regem sublimauit, vt superius declaratur: Stephanus secundus, natione Romanus, ex Patre Constantino, anno Domini septingentesimo quinquagesimo, ab vrbe condita M.DXXX, in summum Pontificem sublimatur. Hic, vt Annonius scribit in gestis Francorum lib. $V$ grauatus a rege Lombardorum Asthulpho, venit in Franciam ad Pipinum regem, anno septingentesimo quinquagesimo tertio, pro iustitia sancti Petri recuperanda, quia ipsum spoliauerat Astulphus... Ob quam causam iterum Pipinus in Italiam contra Astulphum vadit, ipsumque in Papa obsedit, coegitque redderem eum quod promisit. Vadit deinde Pipinus Rauennam, ipsamque; cepit, totamque Pentapolim, Romandiolam cum Marchia \& Bononia victoriose subegit: quae omnia beato Petro studuit reuverenter offerre. Quae beneficia Papa diligenter attendens, ordinauit translationem Romani imperii fieri de Graecis in Francos. Et sic omnes scripturae, quae dicunt quod hic Papa Stephanus secundus, Imperium de Graecis in Francos transtulit: debent intelligi, vt glossemus: Transtulit, id est, translationem fieri ordinauit. Alius enim Pontifex, scilicet Leo tertius, re ipsa imperium transtulit in sequentibus apparebit".

Cap. VI, pág. 92-93

"Hoc itaque Pontifice, scilicet, Stephano secundo, mortuo sub magno ecclesiae protectore Pipino, atque ipso Pipino post decimum octauum annum regni sui, viam uniuersae carnis ingresso, filioque eius Carolo, qui a virtutum magnitudine dictus est Magnus, magnifice pro patre regnante, tribus Pontificibus intermediis, quorum electionem \& vitam causa breuitatis omitto:... Adrianus primus, natione Romanus, ex patre Theodoro de regione Viaelatae, Anno Domini septingentesimo, septuagesimo primo, ab vrbe condita M.DLI. in summum Pontificem eligitur, ecclesiamque Romanam annis XXIII, mensibus decem, \& diebus XVII. prudenter \& magnifice gubernauit. Hic praeciarus Pontifex Adrianus magnificum principem Carolum Magnum, qui tunc, vt dicunt est, Franciae \& Germaniae regna tenebat, in auxilium vocauit contra Lombardos, qui ecclesiam tunc vexabant. Mortuo enim Astulpho Lombardorum rege in regno sucessit Desiderius filius eius... ecclesiam Dei totis viribus opprimebat, villas, ciuitates \& castra, \& alias posessiones ecclesiae violenter usurpans, \& Romanos tyrannico moe premens vectigalibus \& tributis. Ob quam causam, misit Adrianus Legatum in Franciam, Petrum presbyterum Cardinalem ad Carolum Magnum, petens ab eo auxilium contra Desiderium memoratum. Qui gratiose dictum legatum recipiens, congregansque parlamentum Parium \& praelatorum omnium, Pontificis petitioni annuit, dicto legato cum fauore remisso...".

pág. 93.

“...Tunc dictus summus Pontifex Adrianus, mature considerans beneficia tanti principis, ecclesiae Romanae collata, centum quinquaginta trium Episcoporum \& Abbatum Romae Concilium congregauit, ibique Adrianus cum vniversa Synodo, glorioso Carolo hanc tribuit dignitatem: videlicet, ius \& potestatem eligendi Romanum Pontificem, \& Apostolicam sedem ordinandi: Dignitatem Patriciatus quoque ecclesiae concessit... Episcopos \& Archiepiscopos per singulas provincias ab eo inuestituras accipere diffiniunt... Prima siquidem concessione, scilicet... non fuit usus Carolus memoratus... quia pauci summi Pontifices fuerunt tempore sui regiminis... Solus enin praedictus Adrianus \& Leo tertius, praedicti temporis spacio Romani pontifices extiterunt, qui quadraginta \& nouem annis Romanae ecclesiae praefuerunt... De secunda... bene se aliquando intromisit, vt ex gestis suis, in pluribus locis evidenter apparet. Sed his omnibus iuribus, occasione primae \& secundae concessionis competentibus, cessit \& renunciauit Ludouicus Imperator expresse, vt habetur in sexagesima distinctione 
cap.Ludouicus, cum pluribus capitulis sequentibus. Sed vt ad propositum facilius \& citius venire possimus, multa... de gestis Caroli omittimus...".

\section{Capituio VII, pág. 93}

"Mortuo quoque Adriano Papa, praedicto regnante Carolo Magno Ecclesiae defensore, Leo tertius, natione Romanus, ex patre Astulpho, in Romanum Pontificem sublimatur, anno Domini octingentesimo, \& ab Vrbe condita M.DLXXII. Hic pontifex in Laetania maiore Romae captus,exoculatus est, \& lingua detruncatur, qui in custodia positus nocte per murum evasit, \& ad legatos praedicti regis Caroli, scilicet... confugit cum fiducia. Hic gloriosus Pontifex, vt Richardus in suis Chronicis scribit, \& aliae historiae vericicae asserunt, restitutis sibi plenarie membris, scilicet oculis \& lingua, diuina virtute, ad praedictum Carolum Padenbornum, ad precipuum ecclesiae protectorem venit in Franciam...".

\section{Pág. 94}

“...Praedictus rex Carolus... terra Sancta recuperata, per Constantinopolim Romam rediit, ibique natiuitatem Domini solenniter celebrauit cum Leone, ipsa die celeberrima natiuitatis Domini. Cum rex Carolus, in missa ante confessionem Petri surgeret ab oratione deuota, Leo Papa solenniter ordinatis omnibus ad tantam solennitatem necessariis, cornam imperialem capiti eius imposuit, \& a cuncto populo Romano acciamatum est: Carolo Augusto a Deo coronato, Magno et Pacifico Imperatori, Vita et Victoria De Coelo Sibi Ministretur. Hanc siquidem orationem, per Leonem Papam, \& imperialium laudum exclamationem,per plurimum omnes historiae canunt. Sed post praedicta, more antiquorum principum, fuit ab omnibus vniversaliter adoratus. Et ablato Patricii nomine Imperator Avgvstus est ab omnibus appelatus. Rex autem praedictus Carolus, Romanum imperium XXXIII. annis tenuit. Post dictam imperialem coronam, ipsum imperatorem Augustum, omnes annales omnia gesta, omnesque historiae, quae de ipso faciunt mentionem; sine aliqua varietate describunt".

\section{Cap. VIII, pág. 94}

"Quantum autem roboris habuerit, aut firmitatis, quidve tunc per Romanam ecclesiam factum fuerit de Imperio, patet \& patere potest omnibus euidenter. Praedicta enim Imperii translatio facta per Ecclesiam, de Graecis in Francos, ex causis \& rationibus antedictis, adeo valida est, quod per septem generationes, per septem scilicet Imperatores, annis centum tribus durauit, \& amplius, nec defecisset in ipsis monarchia Imperii, nisi virtus \& deuotio erga sanctam Romanam ecclesiam defecisset. Sed virtute ac deuotione deficiente, defecit Imperium. Imperatorem autem Amulphus, vltimus de dicto genere, effoeminatus \& villis fuit, \& in defensionem Ecclesiae non solum remissus \& tepidus contra Berengarium tyrannum, qui tunc in Italia ecclesiam Dei impugnabat, \& alios qui ipsam in multis partibus molestabant: sed ipsemet era Ecclesiae persecutor, vt Martinus Polonus episcopus Consentinus scribit... quia dictus Berengarius ecclesiam molestabat, tum quia ecclesiae non verus pastor, sed mercenarius praeerat, scilicet, Iohannes filius Alberti. Tunc, vt tradit Richardus Cremonensis espiscopus magnus historiarum scriptor, Cardinales de communi concordia, anno natiuitatis Domini DCCCCL. scripserunt Ottoni Duci Saxoniae, qui fuit vir magnae potentiae. Nam in tota Germania dominabitur. Erat enim vir religiosus... in rebus bellicis strenuus... erga Romanam Ecciesiam cum omni veneratione devotus... etiam adiuuaret.Qui... ipsum tyrannum occidit \&Romam pergens concilium Cardinalium congregauit, \& de ipso Concilio Papam videns incorrigibilem, monuit vt Papatui renunciaret. Quem induratum in castro sancti Angeli violenter inclusit, ipsumque renunciare coegit. Factus tunc est Pastor vniuersalis ecclesiae Leo octavus, qui mature considerans beneficium collatum ecclesiae per predictum Ottonem ducem Saxoniae, easdem dignitates Ottoni concessit, quas Carolus contulerat Adrianus, facta Synodo, clero \& populo congregatis, vt patet 61 dist. c. in Synodo. Insuper ipsum imperatorem constituit, nulla precedente electione, quae postea a XLI annis instituta fuit. Et sic facta est translatio de Gallicis in Germanos. Patet ergo quod circa ordinationem imperii, habet Papa maximam potestatem, vt habuit. Siquidem hic Otto primus, ex ordinatione ecclesiae pacifice imperium habuit etiam successiue filius \& nepos... vt de Ottone predicto patet LXIII. dist. c. Tibi Domine. Patet igitur dispositionem \& ordinationem Summi Pontificis circa praedictos Imperatores fuisse legitimam: quia pro bono pacis, \& statu fidei, \& vniversalis ecciesiae, ad quae Summus Pontifex praecipue debet intendere: quia sua interest, non tantum ex collatione imperialium iurium, quantum ex praeminentia status, quae declaratur manifeste in c. Solitae. de maio. \& obe". 
Cap. IX, págs. 94-95

"Post hoc mortuo Ottone tertio sine filiis, Gregorius quintus, natione Theutonicus, de parentela Ottonis, in summum pontificem assumitur. Cuius Pontificis tempore, Electores Imperatoris instituuntur septem, scilicet, Principes Alemaniae, tres praelati, \& quatuor laici, vt Martinus scribit. Quia igitur praedicti Ottones succesiue, \& quasi hereditario iure obtinuerunt imperium, per Gregorium Papam quintum est prouisum, \& vtiliter ordinatum, vt tantae sublimitatis ordinatio, quae non debetur sanguini, sed virtuti, non per viam successionis, sed per electionem procederet... Fuit igitur per dictum Pontificem institutum, vt septem proceres officiales, Imperatorem regem Romanum eligerent, \& per Summum Pontificem confirmandum, \& imperiali diademate coronandum. Quorum sunt tres Praelati, qui sunt... Et quatuor Barones, qui imperialibus seruiunt... Quae ordinatio facta fuit anno Domini M. II vt gesta Germanorum manifeste declarant".

Cap. X, pág. 95

"Ex praedictis igitur euidenter apparet, per Stephanum Papam secundum, tempore Pipini Regis ordinationem praedictam de translatione de Graecis in Francos... \& probationibus supra declaratis factam, vt notatur de elect. Venerabilem... Sed per Leonem tertium translationem realiter factam, de principibus Graecis in Francos,vt notatur de elec. Venerabilem. Vbi expresse scribitur, quod a Leone tertio Caro'us magnus Imperator extitit coronatus: \& postmodum processu temporis... translationem imperii iusta de causa factam esse per Leonem octauum de Gallicis in Germanos, ac postmodum per Gregorium Quintum, electionem Romani Imperii Septem Principibus Alemaniae praedicti fuisse concessam, qui vsque ad moderna tempora Regem Romanorum eilgunt, per Romanum Pontificem coronandum. Sic ergo Regnum mundi translatum est ad Germanos vel Theutonicus, qui \& regimen hactenus habuerunt...". 